УДК 334.72:330.34:005.591.6

DOI 10.15673/fie.v13i4.2215

\author{
Купріна H.M. \\ доктор економічних наук, профресор \\ кафедра обліку та аудиту \\ Одеська національна академія харчових технологій \\ вул. Канатна 112, м. Одеса, Україна, 65039 \\ E-mail: k.natali@ukr.net \\ ORCID ID: 0000-0003-4645-545X
}

\title{
ІННОВАЦІЙНІ ТЕХНОЛОГІЇ ТРАНСФОРМАЦІЙНИХ ЗМІН ДІЯЛЬНОСТІ СУБ'ЄКТІВ НАЦІОНАЛЬНОЇ ЕКОНОМІКИ
}

Стаття присвячена дослідженню теоретичних аспектів сутності та практичних напрямів здійснення економічної трансформації національної економіки та її суб'єктів для забезпечення ефективності їх діяльності та конкурентоспроможності, що дозволило уточнити сутність поняття «економічна трансформація національної економіки та її господарюючих суб'єктів». Для забезпечення конкурентоспроможності та ефективності функціонування такого важливого суб'єкту національної економіки, як харчова промисловість, проведене дослідження дозволило виділити та обґрунтувати, нові категорії понятійно-категоріального апарату теорії національної економіки: «персистентність діяльності суб'єктів харчової промисловості» та «персистентна трансформація суб'єктів харчової промисловості». Доведено, що для збереження українського виробника харчової продукції необхідна персистентна трансфрормація їх діяльності, як напрям інноваційних технологій трансформаційних змін діяльності в сучасних умовах зміни факторів зовнішнього середовища під впливом всього спектру глобалізаційних процесів на національну економіку, на основі запропонованого методичного підходу до оцінки конкурентоспроможності суб'єктів національної економіки, відмінністю якого від існуючих є базування на теорії ефрективної конкуренції та врахування ієрархії рівнів дослідження (мезо-, мікро, міні- та нанорівнів).

Ключові слова: глобалізаційні процеси, суб'єкти національної економіки, економічна трансфрормація, суб'єкти харчової промисловості, інноваційні технології в трансформації діяльності, персистентність, персистентна трансформація, конкурентоспроможність, ефективність функціонування.

This work is licensed under a Creative Commons Attribution 4.0 International License http://creativecommons.org/licenses/by/4.0/

Постановка проблеми та її зв'язок з важливими науковими та практичними завданнями. Економічна глобалізація, як окремий глобалізаційний процес, тісно переплітається, створює основу і домінує в усіх глобалізаційних процесах, а також є чинником розвитку, як національної економіки і забезпечення та підвищення іii конкурентоспроможності, так і окремих іiі суб'єктів, а саме галузей та їх складових - підприємств та їх об'єднань.

Попередньо проведене дослідження підтвердило [1, с. 64-69], що як об'єкт залучення інвестицій економічно розвинутими країнами Україна, розглядається, як великий експортер сировини, що значно стримує не тільки її економічну інтеграцію, а й економічний розвиток, що є негативною тенденцією, але зацікавлена в залученні іноземних інвестицій, основним джерелом яких $є$ ТНК та актуальним питанням в даний час $€$ саме захист національних економічних інтересів країни. Вплив глобалізаційних процесів, фінансово-економічних криз, можуть стати як загрозами, так і можливостями для розвитку національної економіки та іï економічних суб'єктів, причому при різних умовах, факторах, діях та реакції на них з боку уряду країни, підприємств та їх об’єднань, як у галу- зевих, так і міжгалузевих, загрози можуть стати як перевагами забезпечення конкурентоспроможності економіки країни, галузей та підприємств, так і загрозами, і навпаки.

Наше дослідження наслідків впливу глобалізаційних процесів на економіку України в торговельному іiі секторі, а також тенденції у розвитку світової торгівлі [1, с. 31-40], підтвердило необхідність: пошуку методів забезпечення та підвищення конкурентоспроможності суб'єктів підприємницької діяльності економіки України; напрямів державного регулювання, обмеження експансії імпортних товарів та захисту вітчизняного виробника харчової продукції, як стратегічної галузі національної економіки; зміни методів і форм конкурентної боротьби, проведення стратегічної реструктуризації суб'єктів харчової промисловості з метою посилення та закріплення їх, як на національному, так і на світовому ринку, ефективності їх функціонування та конкурентоспроможності на основі застосування інноваційних технологій трансформаційних змін їх діяльності. Все вище наведене підтверджує необхідність проведення додаткових досліджень та актуальність їх обраного напряму. 
Аналіз останніх досліджень і публікацій. Наше дослідження показало [1, с. 112-121; 2, с. 392396], що існує велика кількість підходів до визначення сутності понятійно-категоріального апарату категорій «трансформація» та «економічна трансформація» на різних рівнях дослідження об'єктів - як національної економіки, так й їі суб'єктів. Так, на думку вчених, стусніть економічної трансформації полягає тому, що:

- «реально відбуваються суттєві зміни в економіці і суспільстві незалежно від причин і сил, що викликають ці зміни, i незалежно від змісту i спрямованості змін» [3];

- «в понятті трансформації має на увазі тип економічної системи, що характеризується змінами, структурними перетвореннями, якісними зрушеннями в усіх іï елементах, що носять динамічний характер, які відбуваються протягом певного часу» $[4,5]$;

- «це процес перетворення однієї економічної системи на іншу, супроводжується відмиранням одних елементів, характеристик, властивостей і появою інших» [6, с. 687];

- «це складний процес перетворення економічної системи, який передбачає кількісні та якісні зміни складових системи і сфер суспільного життя» Петришина Н.В. [7, с. 32];

- «це економічна категорія, яка пов'язана 3 економічною сферою, притаманна різним рівням господарювання, відображає складний процес, здійснюється одночасно в просторі і часі, відбувається під впливом об'єктивних і суб'єктивних факторів і ключовою ознакою якого є сукупність змін, які в кінцевому підсумку призводять до новому економічному стану, нових економічних результатів і постановки нових економічних цілей і завдань [8, с. 190];

- «це активне усвідомлення проблем підприємства і практичне впровадження необхідних змін власниками або командою менеджерів. В українських умовах, після проведення діагностики та узгодження стратегії розвитку та плану трансформації з адміністрацією і акціонерами підприємства, трансформацію можна проводити протягом двох основних етапів: перший - зосереджений на термінові заходи, спрямовані на поліпшення загального стану підприємства, поліпшення навичок персоналу і поліпшення іміджу підприємства (підприємство покращує свою господарську діяльність і, що дуже важливо, забезпечує надійність по відношенню до зовнішніх джерел фінансування), як правило, не вимагає великих інвестицій. Другий етап грунтується на умови досягнення першого етапу, забезпечує виживання підприємства впровадженням дорогих проектів, які потребують значних капіталовкладень» [9, с. 104].

Наше дослідження показало [1, с. 112-121; 2, c. 392-396], що більшість вчених розглядають економічну трансформацію частіше з точки зору трансформації суб'єктів національної економіки, наприклад, підприємств та їх об'єднань, але деякі - 3 точки зору трансформації національної економіки як економічної системи або галузі, наприклад, промисловості. Але враховуючи різки зміни зовнішнього середовища та впливу глобалізаційних процесів на національну економіку в сучасних умовах розвитку суспільства та ринкових відносин, необхідні нові - інноваційні технології трансформаційних змін діяльності суб'єктів національної економіки для забезпечення конкурентоспроможності, ефективності функціонування та розвитку на всіх рівнях їх розміщення в національної економічної системі, а також й самої національної економіки будь-якої країни.

Важливим суб'єктом для забезпечення економічної та продовольчої безпеки будь-якої країни, а також розвитку іiї економіки $є$ саме харчова промисловість зі восьма спектром ії суб'єктів, яка є стратегічною галуззю, тому потребує державного регулювання діяльності та підтримки їі функціонування та розвитку. Тому, враховуючи особливості «парадоксу Нейсбітта», як показало наше дослідження [1, с. 8195, 147-148], чим сильніші окремі учасники внутрішнього ринку - харчова промисловість зі усім спектром структурних компонентів - виробників товарів, робіт і послуг, їх об'єднань та формувань, що мають високу конкурентоспроможність, тим вище рівень багатства і міцності внутрішніх зв'язків суспільства конкретної країни - України і, відповідно, глобалізації національної економіки країни та іiї глобальної конкурентоспроможності, що підтверджується виявленими закономірностями та взаємозв'язком між конкурентоспроможністю національної економіки та такого важливого іiі суб'єкта, як харчова промисловість. Тому для забезпечення конкурентоспроможності, ефективності функціонування та розвитку харчової промисловості необхідні додаткові дослідження то пошук інноваційних технологій трансформаційних змін діяльності їі суб'єктів.

Формулювання цілей дослідження. Метою даної статті є дослідження теоретичних та практичних аспектів сутності економічних категорій та напрямів економічної трансформації такого важливого суб'єкту національної економіки, як харчова промисловість для забезпечення ефективності їх діяльності та конкурентоспроможності та розробка методичного підходу трансформаційних змін діяльності іï суб'єктів в сучасних умовах зміни факторів зовнішнього середовища під впливом всього спектру глобалізаційних процесів на національну економіку України та з врахуванням ієрархії рівнів дослідження.

Виклад основних результатів та їх обгрунтування. Наше дослідження показало [1, с.72-74; 2], економічна трансформація національної економіки та iii господарюючих суб'єктів, на нашу думку, залежно від рівня іїі виникнення і цілей iï проведення (макро-, мезо-, міні-, нанорівнів), може бути структурована (рис. 1) на державну (макрорівень дослідження) та приватну - підприємницьку (мезо-, міні-, нанорівні дослідження) та являє собою процес, спрямований на збереження конкурентоспроможності й ефективності діяльності всіх суб'єктів національної економіки, забезпечення формування конкурентних переваг і подальшого ефективного розвитку без радикальних форм перетворення, значно впливає на напрямки позитивного й ефективного розвитку або відповідні зміни діяльності. 


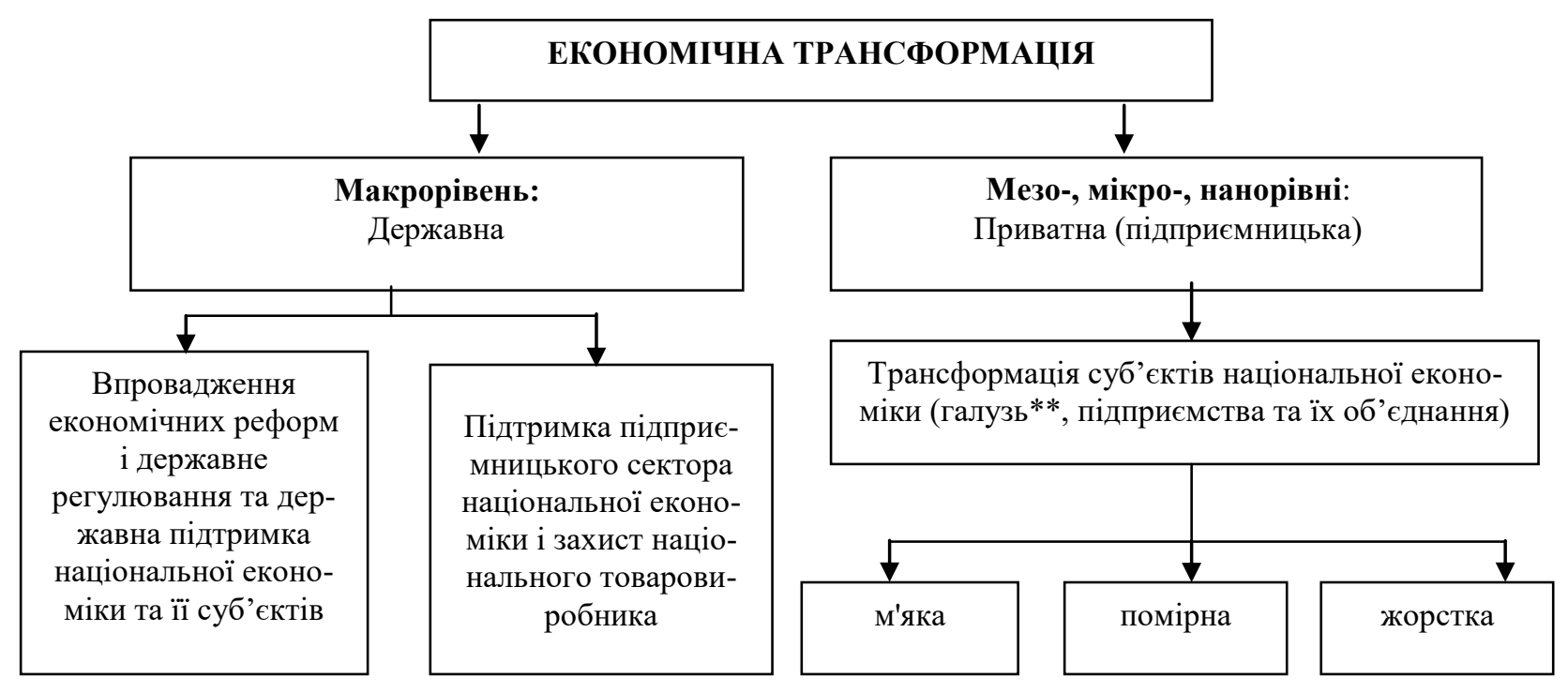

Рис. 1. Підхід до структурування понятійно-категоріального апарату «економічна трансформація» національної економіки в залежності від рівня виникнення і цілей ії проведення*

* складено автором [2, с. 397]

** економічна трансформація галузі може бути розглянута в цілому по країні, тобто на макрорівні дослідження

На нашу думку, якщо розглядати економічну трансформацію національної економіки, необхідно, як показало наше дослідження [2], зосередити свою увагу саме на трансформації діяльності суб'єктів національної економіки, зокрема харчової промисловості та їі суб'єктів, у основі якої лежить саме застосування процесу реструктуризації, яка має стратегічний характер проведення та враховує агресивний вплив факторів зовнішнього середовища. А проведене дослідження [1] дозволило обгрунтувати об'єктивну необхідність проведення реструктуризації харчової промисловості і виділити такий актуальний іiі вид як імпаритетну, що дозволяє зберегти ефективність функціонування і соціальні аспекти діяльності, а також конкурентоспроможність національної економіки та iii суб'єктів в умовах жорсткої конкуренції на внутрішньому ринку України.

Виділення нового виду реструктуризації вимагає обгрунтування методики проведення - оцінки персистентності діяльності та оцінки ступеня трансформації суб'єктів харчової промисловості, а також виділення нових економічних категорій та їх обгрунтування. Це підтверджується необхідністю вираховування прагнення і здатності економічної системи, а саме харчової промисловості та її суб'єктів, не тільки зберігати рівноважний стан, що характеризує стійкість, стабільність, але, разом з тим, мати здатність до розвитку й змін, а при агресивному впливі факторів зовнішнього середовища до стану «завмирання» та «вичікування» для здійсненні своєї діяльності, але не до консервації або ії перепинення. Тому, як показало попереднє дослідження [1, с. 191-193; 2, с. 398-401; 10 с. 5-7], об'єктивним є виділення нової категорії «персистентність» (відображає ступінь економічної стійкості об'єкту дослідження до впливу факторів зовнішнього середовища та відображає достатній рівень ефективності його функціонування і конкурен- тоспроможності) та нового виду трансформації діяльності харчової промисловості та ії суб’єктів - «персистентної трансформації». Даний термін не використовувався в економічній науці та, на нашу думку, може бути застосований не тільки для суб'єктів харчової промисловості, але й для інших галузей для оцінки ефективності їх функціонування та конкурентоспроможності.

За результатами дослідження нами уведено до понятійно-категоріального апарату теорії національної економіки нові категорії:

- «персистентність діяльності суб'єктів харчової промисловості» - відображає ступінь економічної стійкості харчової промисловості та їі суб'єктів як об'єкту дослідження до впливу факторів зовнішнього середовища та достатній рівень ефективності його функціонування і конкурентоспроможності;

- «персистентна трансформація суб'єктів харчової промисловості», яка розуміється як м'яка, помірна або жорстка трансформація власної діяльності суб'єктів харчової промисловості, проведена на основі аналізу персистентності їх діяльності та критеріальної оцінки і спрямована на формування інтегрованих формувань та об'єднань суб'єктів, які в сучасних умовах мають більш високу стійкість до «виживання» на внутрішньому ринку i можливість забезпечення конкурентоспроможності та підвищення ефективності власної діяльності і подальшого розвитку, а, отже, здатності до активної конкуренції на міжнародних ринках.

Як уже було обгрунтовано вище, на нашу думку, для аналізу ступеню персистентності діяльності необхідно застосувати методи, що дозволять оцінити ефективність функціонування та конкурентоспроможність харчової промисловості та іiі суб'єктів за окремими рівнями дослідження (рис. 2) на підставі застосування інструментів аналізу [1, с. 194-196]: 


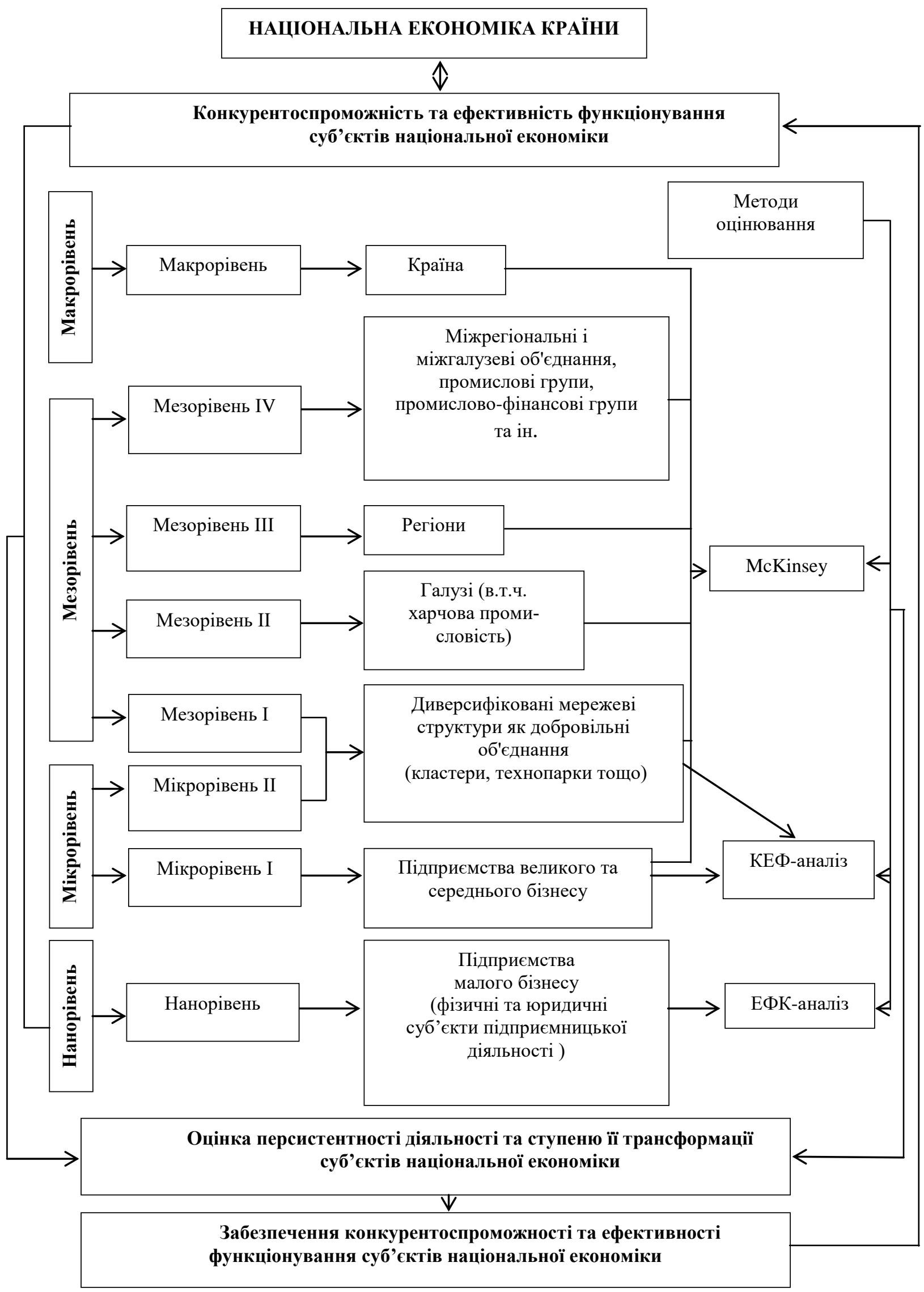

Рис. 2. Підхід до проведення персистентної трансформації харчової промисловості в системі забезпечення її конкурентоспроможності*

*джерело: розробка автора [1, с. 195] 
- метод стратегічного аналізу McKinsey на макро- та мезорівнях дослідження для галузі в цілому (регіональний та національний рівні дослідження), який обгрунтовано, сформовано та розраховано для харчової промисловості на прикладі даних Одеської області в регіональному вимірі, сформовано шкалу оцінювання та напрями розвитку;

- на мезо-, мікро-, мінірівнях дослідження суб'єктів харчової промисловості (великий та середній бізнес) - КЕФ-аналіз, який потребує вдосконалення та включення до системи аналізу ефективності функціонування запропонованого методичного підходу до оцінки результативності їх діяльності за фінансовою складовою, а не тільки фінансових результатів за абсолютними показниками за видами діяльності;

- на нанорівні дослідження суб'єктів харчової промисловості (малий бізнес) - ЕФК-аналіз, який також потребує вдосконалення та включення в систему аналізу ефективності функціонування запропонований методичній підхід до оцінки результативності їх операційної діяльності за фінансовою складовою.

Запропонований методичний підхід до оцінки результативності діяльності суб'єктів харчової промисловості за фінансовою складовою, а не тільки фінансових результатів за абсолютними показниками за видами діяльності, базується на комплексному підході й охоплює два напрями: перший - аналіз фінансових результатів за абсолютними та відносними показниками; другій - аналіз власного капіталу за абсолютними та відносними показниками).

Розроблено види персистентної трансформації залежно від рівня оцінювання суб'єктів харчової промисловості в системі забезпечення їх конкурентос проможності, які враховують [1, с. 197-199]: метод оцінювання; комплексність підходу оцінювання; шкалу оцінювання; отриманий результат такого процесу оцінювання.

Нами формована система критеріальної оцінки персистентної трансформації харчової промисловості, в контексті забезпечення пї конкурентоспроможності, з видаленням [1, с. 197-199; 10, с. 6-7]: виду такої трансформації: м'яка, помірна, жорстка; оцінювання загальних показників конкурентоспроможності харчової промисловості та іiі суб'єктів за обраними методами та рівнями дослідження - мезо-, мікро-, міні- та нанорівнями; оцінювання часткових показників оцінки ефективності функціонування суб'єктів харчової промисловості за мезо-, мікро-, міні- та нанорівнями дослідження, з урахуванням наявності або відсутності нормативних значень.

Висновки та перспективи подальших досліджень. Проведене дослідження дозволяє стверджувати, що «економічна трансформація національної економіки та їі господарюючих суб'єктів», як один із структурних компонентів стратегічної реструктуризації, що представляє собою процес, спрямований на збереження конкурентоспроможності й ефективності діяльності всіх суб'єктів національної економіки, забезпечення формування конкурентних переваг і подальшого ефективного розвитку без радикальних форм перетворення, значно впливає на напрямки позитивного й ефективного розвитку або відповідні зміни діяльності. Якщо розглядати економічну трансформацію національної економіки, необхідно зосередити свою увагу саме на трансформації діяльності суб'єктів національної економіки, зокрема харчової промисловості та іiі суб'єктів, в основі якої лежить саме застосування процесу реструктуризації, яка має стратегічний характер проведення та враховує агресивний вплив факторів зовнішнього середовища.

У контексті проведеного дослідження та використання інноваційних технологій трансформаційних змін діяльності харчової промисловості України та іiі суб'єктів для забезпечення конкурентоспроможності та ефективності функціонування в сучасних умовах господарювання, об'єктивним стало виділення нових економічних категорій: «персистентність діяльності суб'єктів харчової промисловості» - відображає ступінь економічної стійкості харчової промисловості та іiі суб'єктів як об'єкту дослідження до впливу факторів зовнішнього середовища та достатній рівень ефективності його функціонування і конкурентоспроможності; «персистентна трансформація суб'єктів харчової промисловості», яка розуміється як м'яка, помірна або жорстка трансформація власної діяльності суб'єктів харчової промисловості, проведена на основі аналізу персистентності їх діяльності та критеріальної оцінки і спрямована на формування інтегрованих формувань та об'єднань суб'єктів, які в сучасних умовах мають більш високу стійкість до «виживання» на внутрішньому ринку і можливість забезпечення конкурентоспроможності та підвищення ефективності власної діяльності і подальшого розвитку, а, отже, здатності до активної конкуренції на міжнародних ринках.

Нами обгрунтовано, що для аналізу персистентності діяльності необхідно застосувати методи, які дозволять оцінити ефективність функціонування та конкурентоспроможність харчової промисловості та іiї суб'єктів за окремими рівнями дослідження на підставі застосування інструментів аналізу: метод стратегічного аналізу McKinsey на макро- та мезорівнях дослідження для галузі в цілому та сформовано шкалу оцінювання і напрями розвитку оцінювання та напрями розвитку; на мезо-, мікро-, мінірівнях дослідження суб'єктів харчової промисловості (великий та середній бізнес) - КЕФ-аналіз та на нанорівні дослідження суб'єктів харчової промисловості (малий бізнес) - ЕФК-аналіз, що удосконалено нами.

\section{Література}

1. Купріна Н.М. Забезпечення конкурентоспроможності харчової промисловості України: теорія i практика: монографія. Одеса: Видавничий дім «Гельветика», Одеса. 2019. 304 с. 
2. Kuprina N. Persistent transformation of the subjects of the national economy as a tool to ensure their competitiveness // Gospodarka Materialowa I Logistyka, Tom LXXI. №5. 2019. P. 388-404. URL: http://bazekon.icm.edu.pl/bazekon/element/bwmeta1.element.ekon-element-000171576820 (дата звернення: 01.11.2021).

3. Хубиев К.А. Функционально-генетический подход к оценке трансформационных процессов // Экономическая трансформация и трансформационный процесс. Москва: ТЕИС, 1999. С. 24-33.

4. Веслогузова М. В. Трансформация инвестиционных отношений в экономической системе // Проблемы современной экономики. 2010. № 1 (33). URL: http://www.m-economy.ru/art.php?nArtId=2970 (дата 3вернення: 01.11.2021).

5. В поисках новой теории / под ред. А.Г. Грязновой, Н.Н. Думной. Москва: КНОУРС, 2004.

6. Економічна енциклопедія: у 3 т. / за ред. Б.Д. Гаврилишин, С.В. Мочерний. К.: Акад.; Т.: Акад. нар. госп-ва, 2002. Т. 3. (Поручництво) - Я (Японський центр продуктивності). П - Я. 952 с.

7. Петришина Н.В. Проблеми трансформації економіки України // Економіка. 2014. Вип. 24. С. 31-38. URL: http://enpuir.npu.edu.ua/bitstream/123456789/7394/1/Petryshyn\%D0\%B0.pdf. (дата звернення: 01.11.2021).

8. Турило А.М., Корнух О.В. «Економічна трансформація» як ключове поняття сучасного громадського розвитку // Науковий вісник херсонського державного університету. В.3. Ч.3. 2014. C. 189-191. URL: http://www.ej.kherson.ua/journal/economic_06/177.pdf (дата звернення: 01.11.2021).

9. Марчук Л.В., Смиковчук Т.В., Кондур О.С. Трансформація підприємств та реінжиніринг бізнеспроцесів як базові технології управління: Електроний ресурс // Lviv Polytechnic National University Institutional Repository. 2006 URL: http://ena.lp.edu.ua:8080/bitstream/ntb/30394/1/Vis_570_Menedgment.\%20103-106.pdf (дата звернення: 01.11.2021).

10. Купріна Н.М. Розвиток сучасних бізнес-стратегій та аутсорсингової діяльності суб'єктів національної економіки: сутність та напрями // Економіка харчової промисловості. 2021. Т. 13, вип. 2. С. 3-8. doi: 10.15673/fie.v13i2.2034

Стаття надійшла 7.11.2021

Стаття прийнята до друку 21.11.2021

Доступно в мережі Internet 30.12.2021

\author{
Kuprina N. \\ Doctor of Economics, Professor \\ Department of Accounting and Auditing \\ Odessa National Academy of Food Technologies \\ Kanatna str., 112, Odesa, Ukraine, 65039 \\ E-mail:k.natali_@ukr.net \\ ORCID ID: 0000-0003-4645-545X
}

\title{
INNOVATIVE TECHNOLOGIES OF TRANSFORMATION CHANGES OF SUBJECTS' ACTIVITIES IN THE NATIONAL ECONOMY
}

The article is devoted to the study of theoretical aspects of the essence and practical directions of economic transformation of the national economy and its subjects to ensure the efficiency of their activities and competitiveness, which clarified the essence of the concept of "economic transformation of the national economy and its economic entities" as the process aimed at maintaining the competitiveness and efficiency of all subjects of the national economy, ensuring the formation of competitive advantages and further effective development without radical forms of transformation, significantly affecting the areas of positive and effective development or appropriate changes. To ensure the competitiveness and efficiency of such an important subject of the national economy as the food industry, the study identified and substantiated new categories of conceptual and categorical apparatus of national economic theory: "persistence of food industry" and "persistent transformation of the subjects of food industry ". It has been proved that keeping of Ukrainian food producers requires persistent transformation of their activities as a direction of innovative technologies of transformational changes in modern conditions of change of environmental factors under the influence of the whole spectrum of globalization processes on the national economy on the basis of the proposed methodological approach to estimation of competitiveness of the subjects of the national economy, which differs from the existing ones based on the theory of effective competition and taking into account the hierarchy of levels of the research (meso, micro, mini and nano levels) and based on the use of analysis tools (McKinsey's method of strategic analysis at the macro and meso levels of the research for the industry as a whole and an evaluation scale and directions of evaluation and directions of development have been formed; directions at the meso, micro and mini levels of the medium business research) - CEF analysis; nano-level research of food industry entities (small business) - EFC analysis) have also been carried out.

Key words: globalization processes, subjects of national economy, economic transformation, subjects of food industry, innovative technologies in transformation of activity, persistence, persistent transformation, competitiveness, efficiency of functioning. 


\section{References}

1. Kuprina, N. M. (2019). Zabezpechennia konkurentospromozhnosti kharchovoi promyslovosti Ukrainy: teoriia i praktyka. Vydavnychyi dim «Helvetyka».

2. Kuprina, N. (2019). Persistenttrans formation of the subjects of the national economy as a tool to ensure their competitiveness: Experience of Ukraine. Gospodarka Materialowa I Logistyka, LXXI(5), 388-404. Retrieved November 11, 2021, from http://bazekon.icm.edu.pl/bazekon/element/bwmeta1.element.ekon-element-000171576820

3. Hubiev, K. A. (1999). Funktsionalno-geneticheskiy podhod k otsenke transformatsionnyih protsessov. Ekonomicheskaya transformatsiya i transformatsionnyiy protsess. TEIS, 24-33.

4. Vesloguzova, M. V. (2010). Transformatsiya investitsionnyih otnosheniy v ekonomicheskoy sisteme. Problemyi sovremennoy ekonomiki, 1(33). Retrieved November 11, 2021, from http://www.meconomy.ru/art.php?nArtId=2970

5. Gryaznova, A. G., \& Dumna, N. N. (Eds.). (2004). V poiskah novoy teorii . KNOURS.

6. Havrylyshyn, B. D., \& Mochernyi, S. V. (Eds.). (2002). Ekonomichna entsyklopediia (Vol. 3). Akad.; Akad. nar.hosp-va.

7. Petryshyna, N. V. (2014). Problemy transformatsii ekonomiky Ukrainy. Ekonomika, (24), 31-38. Retrieved November 01, 2021, from http://enpuir.npu.edu.ua/bitstream/123456789/7394/1/Petryshyn\%D0\%B0.pdf.

8. Turylo, A. M., \& Kornukh, O. V. (2014). «Ekonomichna transformatsiia» yak kliuchove poniattia suchasnoho hromadskoho rozvytku. Naukovyi visnyk khersonskoho derzhavnoho universytetu, 3, Ch.3, 189-191. Retrieved November 01, 2021, from http://www.ej.kherson.ua/journal/economic_06/177.pdf

9. Marchuk, L. V., Smykovchuk, T. V., \& Kondur, O. S. (2006). Transformatsiia pidpryiemstv ta reinzhynirynh biznes-protsesiv yak bazovi tekhnolohii upravlinnia. Retrieved November 01, 2021, from http://ena.lp.edu.ua:8080/bitstream/ntb/30394/1/Vis_570_Menedgment.\%20103-106.pdf

10. Kuprina, N. M. (2021). Rozvytok suchasnykh biznes-stratehii ta autsorsynhovoi diialnosti sub'iektiv natsionalnoi ekonomiky: sutnist ta napriamy. Ekonomika kharchovoi promyslovosti, 13(2), 3-8. doi: 10.15673/fie.v13i2.2034

Received 7 November 2021

Approved 21 November 2021

Available in Internet 30.12.2021

Цитування згідно ДСТУ 8302:2015

Купріна Н.М. Інноваційні технології трансформаційних змін діяльності суб'єктів національної економіки // Економіка харчової промисловості. 2021. Т. 13, вип. 4. С. 3-9. doi 10.15673/fie.v13i4.2215

Cite as APA style citation

Kuprina, N. (2021). Innovative technologies of transformation changes of subjects' activities in the national economy. Food Industry Economics, 13(4), 3-9. doi 10.15673/fie.v13i4.2215 